\title{
Membangun Media Massa Publik dalam Menanamkan Pendidikan Karakter
}

\author{
Oos M. Anwas \\ oos.anwas@kemdiknas.go.id
}

\begin{abstract}
ABSTRAK: Dalam era informasi, penanaman pendidikan karakter perlu dilakukan melalui media massa publik. Exposure media massa yang dikuasai swasta seringkali diwarnai kepentingan ideologi, pemilik (owner), serta keuntungan finansial. Oleh karena itu, diperlukan media massa publik yang memiliki idealisme untuk mengutamakan kepentingan masyarakat. Bentuknya, yaitu Koran Publik, Majalah Publik, Radio Publik, Televisi Publik, dan Web/Portal Publik. Untuk dapat menanamkan pendidikan karakter, substansi media massa publik perlu dirancang sesuai dengan kebutuhan dan karakter sasaran, distribusinya dilakukan secara kontinyu, mudah diakses atau dimanfaatkan oleh sasaran, serta dikemas dalam format yang menarik dan mampu bersaing dengan media massa swasta. Substansi media ini dituntut dapat mendorong dan menciptakan masyarakat pembelajar, menjadi inspirasi, mencerdaskan, serta memberikan contoh keteladanan dalam membangun karakter bangsa. Untuk merealisasikan media massa publik dapat dikembangkan dari lembaga yang ada, misalnya RRI, TVRI, atau kantor berita Antara dengan cara mensinergikan dengan potensi yang dimiliki kementerian atau lembaga-lembaga lainnya baik dalam aspek: substansi, infrastruktur, SDM, dan aspek lainnya.
\end{abstract}

Kata kunci: media massa publik, koran publik, majalah publik, radio publik, televisi publik, web/portal publik, dan pendidikan karakter

\begin{abstract}
In the information era, character education is necessary to be done through mass media. Privately-controlled mass media is often marred by ideological and owner's interests as well as by financial benefits. Therefore we need a public mass media with public interest idealism. It could be in the form of public newspaper, public magazine, public radio, public television, or public web/portal. To be able to Incalculate character education, substance of the public mass media should be designed in accordance with the needs and character of the target, distributed continuously, easily accessed or utilized by the target, and packaged in an attractive format to enable it to compete with other mass media. The substance is required to encourage and create a community of learners, inspire, educate, and provide examples in building the nation's character. To realize that the public mass media can be developed from existing institutions such as RRI, TVRI, or Antara News Agency in a synergistic manner with all potential in ministries or other institutions in the aspect of substance, infrastructure, human resources, etc.
\end{abstract}

Keywords: public mass media, public newspapers, magazines, public, public radio, public television, web/public portals, and character education.

\section{Pendahuluan}

Pendidikan karakter merupakan salah satu program prioritas Kementerian Pendidikan dan Kebudayaan. Pentingnya menanamkan pendidikan karakter ini didasarkan pada realialitas dalam masyarakat terjadi adanya kecenderungan merosotnya tatanan nilai, norma, dan perilaku yang menjadi jati diri bangsa. Perilaku kejahatan seperti kekerasan, perampokan, atau tawuran seringkali menghiasi berita dan buah bibir di masyarakat. Dalam kalangan intelektual, perilaku korupsi, kolusi, nepotisme, bahkan plagiat masih sering ditemukan. Begitu pula dalam perilaku keseharian, sudah semakin menurunya tatanan nilai dan kearifan-kearifan lokal, misalnya merosotnya sopan santun anak terhadap orang tua atau guru, pelanggaran terhadap adat dan kebiasaan, westernisasi yang kurang sesuai dengan adat ketimuran, menurunnya sifat gotong royong, dan banyak hal yang begitu mudah ditemukan di masyarakat. Akibat seringnya terjadi tindakan penyimpangan tersebut, seolah-olah perbuatan itu menjadi perilaku yang lumrah, padahal sesungguhnya telah menyimpang dari karakter bangsa.

Membangun kembali pendidikan karakter tidak 
sekedar mentrasnfer ilmu pengetahuan atau nilainilai tertentu. Pendidikan karakter tidak hanya aspek pengetahuan, akan tetapi meliputi aspek sikap, kepribadian, dan keterampilan yang diwujudkan dalam perilaku individu. Oleh karena itu, menanamkan pendidikan karakter merupakan upaya mengubah perilaku nyata dalam kehidupan seharihari. Itulah sebabnya membangun pendidikan karekter diperlukan adanya pembiasaan, penguatan, dan pengkondisian lingkungan yang sesuai dengan jati diri dan karakter bangsa.

Pembiasaan dan pengkondisian lingkungan ini menurut teori-teori perubahan perilaku mazhab behavioristik sangat penting dalam mengubah perilaku. Di sisi lain, pembentukan perilaku khususnya pada anak-anak dan remaja menurut teori belajar sosial diperlukan adanya modeling atau contoh nyata dalam penerapan kehidupan sehari-hari. Penerapan pendidikan karakter khususnya pada anak-anak jelas perlu contoh dari orangtua, guru, tokoh masyarakat, tokoh agama, dan juga para selebritis yang menjadi idolanya. Mereka dituntut untuk menjadi panutan anakanak dan remaja dalam berpilaku keseharian.

Pada era teknologi informasi dan komunikasi sekarang ini, panutan anak-anak dan remaja tidak hanya ditemukan dalam lingkungan kehidupan keseharian mereka. Idola anak-anak dan remaja justru seringkali ditemukan melalui media massa. Manusia merupakan mahluk peniru dan imitatif. Perilaku imitatif ini sangat menonjol pada sifat anak-anak dan remaja. Kemampuan berpikir anakanak dan remaja masih relatif sederhana. Sikap dan perilaku selebritis yang ditampilkan di media seringkali begitu mudah ditiru oleh anak-anak dan remaja dibandingkan meniru orangtua atau gurunya. Gencarnya exposure media massa terutama televisi dan internet membuat khawatir masyarakat terutama para orang tua. Anak-anak dan remaja masih sulit memilih perilaku yang baik sesuai dengan nilai dan norma agama serta karakter bangsa. Adegan kekerasan, kejahatan, glamour, konsumtif, termasuk perilaku seksual media massa diduga kuat berpengaruh terhadap pembentukan perilaku anak. Itulah sebabnya diperlukan peran aktif dari media massa dalam membentuk karakter bangsa.

Media massa mempunyai fungsi sebagai media informasi, hiburan, dan juga pendidikan. Namun dalam kenyataanya media massa lebih banyak menonjol- kan aspek hiburan. Substansi media massa terutama milik swasta didorong oleh kepentingan bisnis, kepentingan dan ideologi pemilik (owner), serta tentu saja mencari keuntungan. Oleh karena itu, diperlukan media massa yang memiliki idealisme kuat dalam menanamkan karakter bangsa yang dapat menjadi panutan atau idola anak-anak dan remaja. Untuk mewujudkan hal itu diperlukan pembangunan media massa publik yang mengutamakan kepentingan masyarakat, membangun masyarakat khususnya menanamkan pendidikan karakter bangsa. Penulisan ini bertujuan mengkaji tentang perlunya merealisaikan media massa publik yang memiliki idealisme dan berpihak pada masyarakat dalam membangun pendidikan karakter bangsa.

\section{Kajian Literatur dan Pembahasan Pendidikan Karakter}

Dalam Undang-Undang Nomor 20 Tahun 2003 tentang Sistem Pendidikan Nasional Pasal 1 ditegaskan bahwa pendidikan adalah usaha sadar dan terencana untuk mewujudkan suasana belajar dan proses pembelajaran agar peserta didik secara aktif mengembangkan potensi dirinya untuk memiliki kekuatan spiritual keagamaan, pengendalian diri, kepribadian, kecerdasan, akhlak mulia, serta keterampilan yang diperlukan dirinya, masyarakat, bangsa dan negara. Selanjutnya dalam Pasal 3, ditegaskan bahwa pendidikan nasional berfungsi mengembangkan kemampuan dan membentuk watak serta peradaban bangsa yang bermartabat dalam rangka mencerdaskan kehidupan bangsa, bertujuan untuk berkembangnya potensi peserta didik agar menjadi manusia yang beriman dan bertakwa kepada Tuhan Yang Maha Esa, berakhlak mulia, sehat, berilmu, cakap, kreatif, mandiri, dan menjadi warga negara yang demokratis serta bertanggung jawab.

Dengan acuan tersebut nampak jelas bahwa tujuan pendidikan tidak sekedar menciptakan manusia yang pintar, cerdas, atau menguasai ilmu pengetahuan dan teknologi saja. Pendidikan adalah membangun manusia yang utuh antara jasmani dan rohani, keseimbangan antara kecerdasan dalam berpikir, sikap, dan serta ahlak mulia yang sesuai dengan tatanan nilai dan norma yang ada di masyarakat dan tuntunan ajaran agama.

Pendidikan karakter hakikatnya merupakan pengintegrasian antara kecerdasan, kepribadian, dan 
akhlak mulia. Menurut Lickona (Elkind dan Sweet, 2004) pendidikan karakter merupakan upaya membantu peserta didik untuk memahami, peduli, dan berbuat atau bertindak berdasarkan nilai-nilai dan etika. Pendidikan karakter merupakan upaya menanamkan kecerdasan dalam berpikir, penghayatan dalam bentuk sikap, dan pengamalan dalam bentuk perilaku yang sesuai dengan nilai-nilai luhur yang menjadi jati dirinya, diwujudkan dalam berinteraksi dengan Tuhannya, diri sendiri, antar sesama, dan lingkungannya (Anwas, 2010). Nilainilai luhur tersebut antara lain: kejujuran, kemandirian, sopan santun, kemuliaan sosial, serta kecerdasan berpikir termasuk kepenasaranan akan intelektual dan berpikir logis.

Dalam grand desain Kementerian Pendidikan dan Kebudayaan (Kemdiknas, 2010), pendidikan karakter merupakan proses pembudayaan dan pemberdayaan nilai-nilai luhur dalam lingkungan satuan pendidikan (sekolah), lingkungan keluarga, dan lingkungan masyarakat. Nilai-nilai luruh tersebut berasal dari: teori-teori pendidikan, psikologi pendidikan, nilai-nilai sosial budaya, ajaran agama, Pancasila dan UUD 1945 serta UU No 20 Tahun 2003 tentang Sistem Pendidikan Nasional, serta pengalaman terbaik dan praktik nyata dalam kehidupan sehari-hari. Proses pembentukan karakter ini terjadi di lingkungan pendidikan, lingkungan keluarga, dan lingkungan masyarakat. Ketiga lingkungan tersebut memiliki kontribusi dalam membentuk karakter bangsa. Oleh karena itu, perlu adanya keseimbangan dalam mewujudkan karakter bangsa yang sesuai dengan harapan. Proses pembudayaan dan pemberdayaan nilai-nilai luhur tersebut juga perlu didukung oleh komitmen dan kebijakan pemangku kepentingan serta pihak-pihak terkait lainnya termasuk dukungan sarana dan prasarana yang diperlukan.

Membangun pendidikan karakter tidak bisa hanya sekadar menstranfer ilmu pengetahuan atau melatih suatu keterampilan tertentu. Pendidikan karakter tidak cukup dilakukan melalui sebuah proses mengajarkan mata pelajaran tentang sikap hidup baik dan benar atau materi budi pekerti saja. Pendidikan karakter perlu adanya pembiasaan dengan menciptakan lingkungan yang kondusif yang dapat mempe-ngaruhi peserta didik baik di lingkungan sekolah, lingkungan keluarga, dan lingkungan masyarakat. Dalam era informasi sekarang, ketiga lingkungan tersebut tidak lepas dari pengaruh media massa. Anak-anak dan remaja serta orangtua hampir setiap hari mendapatkan terpaan (exposure) dari berbagai media massa. Terpaan media massa yang dilakukan secara terus menerus ini akan memberikan dampak terhadap pembentukan perilaku. Oleh karena itu, menanamkan pendidikan karakter perlu kerjasama semua pihak terkait, termasuk media massa. Sekolah dituntut untuk dapat mengintegrasikan proses pembelajaran setiap mata pelajaran, pembiasaan dalam interaksi keseharian di sekolah, termasuk dalam kegiatan ekstra kurikuler oleh semua personil sekolah mulai dari siswa, guru, kepala sekolah, dan tenaga kependidikan. Begitu pula di lingkungan keluarga, lingkungan masyarakat, termasuk exposure media massa perlu memberikan contoh nyata dan lingkungan yang kondusif dalam membentuk pendidikan karakter.

\section{Media Massa dalam Mempengaruhi Perilaku}

Hakekat komunikasi massa adalah proses komunikasi yang dilakukan melalui media massa. Ciri utama komunikasi massa antara lain: sumber komunikasi massa bukanlah perorangan tetapi organisasi formal (komunikator profesional; pesan diproses, distandarisasi, dan selalu diperbanyak); disamping itu pesan juga merupakan suatu produk dan komoditi yang memiliki nilai tukar, serta acuan simbolik yang mengandung nilai "kegunaan" (McQual, 1987).

Media massa dapat dikelompokkan dalam dua golongan yaitu media cetak dan media elektronik. Media cetak terdiri dari koran, majalah, taboloid, dan bentuk cetak lainnya. Media massa elektronik terdiri dari: radio, televisi, film, dan internet (media online), dan bentuk lainnya. Dalam perkembangan di era teknologi internet sekarang, hampir semua media cetak memiliki versi online yang bisa diakses melalui internet.

Teori Jarum Hipodermik yang didasari oleh teori Stimulus Respon, menjelaskan bahwa isi media dipandang sebagai obat yang disuntikan ke dalam pembuluh darah audience, yang diasumsikan akan bereaksi seperti yang diharapkan (Sandjaja dan Sumawinardi, 1994). Teori klasik ini berasumsi bahwa media massa memiliki pengaruh yang besar terhadap masyarakat. Teori Agenda-setting diperkenalkan oleh McCombs dan DL Shaw (McQuail dan Windahl, 1996). Inti pemikiran teori ini berkaitan dengan fungsi 
belajar dari media massa. Diasumsikan bahwa khalayak tidak hanya mempelajari isyu-isyu pemberitaan, tetapi juga mempelajari seberapa besar arti penting diberikan pada suatu isyu atau topik berdasarkan cara media massa memberikan penekanan terhadap isyu atau topik tersebut. Asumsi teori ini adalah bahwa jika media memberi tekanan pada suatu peristiwa, maka media itu akan mempengaruhi khalayak untuk menganggapnya penting.

Masyarakat atau khalayak sesungguhnya dapat mempengaruhi isi media massa. Khalayak dapat memilih media massa yang sesuai dengan kebutuhan dan permasalahan yang dihadapinya. Dengan kata lain masyarakat memiliki kekuasaan untuk memilih media massa yang sesuai dengan kebutuhan dan kepentingannya Hal tersebut dijelaskan oleh teori komunikasi massa Uses and Gratifications (Suresh, 2003). Media massa yang tidak sesuai dengan kebutuhan masyarakat akan ditinggalkan. Dengan demikian media massa dituntut mengikuti kebutuhan masyarakat. Masalahnya adalah penerapan teori ini perlu adanya kesadaran dan kemampuan masyarakat untuk memilih dan mempengaruhi media tersebut. Di sisi lain, diperlukan adanya berbagai alternatif media massa sehingga masyarakat bisa memilih. Perkembangan yang terjadi sekarang adalah adanya hegemoni media, dimana media massa dikuasai oleh satu atau beberapa konglomerasi tertentu. Adanya penguasaan terhadap berbagai media oleh satu konglomerasi atau satu kepemilikan ini tentu saja akan memberikan pengaruh terhadap substansi dari media massa tersebut. Akibatnya alternatif pilihan media dalam masyarakat menjadi terbatas. Kondisi seperti inilah yang mendorong perlunya ada media massa alternatif yang memiliki idealisme kuat dalam mengutamakan kepentingan masyarakat. Media massa tersebut adalah media massa publik.

Banyak kajian dan pengalaman empirik yang meyakini keampuhan media massa dalam mempengaruhi masyarakat. Media massa seringkali dijadikan wahana promosi produk barang atau jasa dalam mempengaruhi konsumen untuk tertarik dan membeli produk tersebut. Media massa juga diyakini mampu meningkatkan popularitas dan citra individu menjadi dikenal masyarakat. Setiap menjelang pemilihan umum atau pemilihan kepala daerah, banyak calon legislatif, calon presiden, atau calon kepala daerah yang mempromosikan diri melalui media massa baik cetak maupun elektronik. Walaupun kiprah atau prestasi individu tersebut belum ada, tetapi dengan tampil di media massa maka akan dikenal oleh masyarakat. Para kandidat tidak sedikit yang membayar mahal konsultan media untuk memolas dirinya agar citra dan reputasinya meroket dan dikenal masyarakat. Kondisi ini merupakan bukti bahwa media massa sudah mendapatkan tempat dan menjadi bagian keseharian di masyarakat.

Pertanyaan yang mendasar adalah karakte-ristik media seperti apa yang bisa mempengaruhi masyarakat tersebut. Anwas (2009) melakukan penelitian exploratif pengaruh media massa terhadap peningkatan kompetensi penyuluh pertanian di Jawa Barat. Media massa yang diteliti adalah koran, majalah, buku, radio, televisi, dan internet. Hasil uji regresi berganda diketahui bahwa media massa yang berpengaruh signifikan terhadap kompetensi penyuluh hanya majalah. Anwas melakukan pendalaman atas hasil uji statistik tersebut diketahui bahwa majalah yang dimiliki dan sering dibaca penyuluh adalah Majalah Sinar Tani. Majalah Sinar Tani ini diterbitkan secara berkala dua kali dalam sebulan oleh PT Duta Karya Swasta yang bekerjasama dengan Kementerian Pertanian Republik Indonesia. Distribusinya dilakukan secara langsung dan kontinyu kepada para penyuluh pertanian PNS di lapangan. Subtansi majalah berisi tentang masalah dan solusi yang berkaitan dengan pertanian. Topik-topik aktual yang terkait dengan pertanian menjadi bahasan utama majalah Sinar Tani. Majalah ini juga menyajikan inovasi atau teknologi baru, kajian permasalahan pertanian, sharing pengalaman, dan juga sebagai media komunikasi, sehingga sesuai dan mendukung terhadap kegiatan penyuluhan pertanian.

Media massa lain yang diteliti Anwas (2009) adalah koran, buku, radio, televisi, dan internet. Pemanfaatan koran tidak berpengaruh secara nyata terhadap kompetensi. Hal ini disebabkan karena: informasi/substansi koran kurang sesuai dengan penyuluhan, masih belum ada koran (harian) yang secara khusus membahas tentang pertanian seperti halnya majalah Sinar Tani, penyuluh yang umumnya tinggal di pedesaan/kota kecamatan sulit dijangkau dengan koran harian, dan intensitas pemanfaatan koran sangat rendah. 
Intensitas pemanfaatan buku menunjukkan tidak berpengaruh nyata terhadap kompetensi penyuluh, padahal jika diperhatikan substansi buku yang dibaca penyuluh sesuai dengan penyuluhan. Hal ini dipengaruhi oleh tingkat pemanfaatanya sangat rendah. Di sisi lain, tingkat ketertarikan membaca buku lebih rendah dibandingkan dengan membaca koran atau majalah. Intensitas pemanfaatan media radio juga tidak berpengaruh terhadap kompetensi penyuluh. Hal ini dapat dianalisis bahwa sebagian besar acara radio yang diikuti penyuluh bersifat hiburan, begitu pula data stasiun radio yang sering didengarkan penyuluh sebagian besar adalah radio swasta yang materi siaranya didominasi oleh unsur hiburan. Padahal radio memiliki karakteristik yang mudah dibawa dan dimanfaatkan termasuk bisa didengarkan sambil bekerja (lebih praktis) dibandingkan dengan media massa baik cetak maupun media elektronik lainnya.

Media televisi seperti halnya dalam masyarakat Indonesia merupakan media massa yang paling digemari masyarakat. Media televisi juga memiliki karakteristik yang mampu menampilkan pesan audio visual dan unsur gerak yang identik dengan media hiburan dan informasi. Kondisi ini juga terjadi pada penyuluh, bahwa intensitas pemanfaatan televisi sangat tinggi tetapi substansinya kurang sesuai dengan penyuluhan sehingga tidak berpengaruh nyata terhadap peningkatan kompetensi penyuluh. Jika media ini dimanfaatkan secara kontinyu dan substansi yang relevan dengan penyuluhan, maka dapat ditafsirkan bahwa media televisi memiliki potensi untuk berpengaruh terhadap kompetensi penyuluh.

Internet merupakan media yang paling sedikit dimanfaatkan penyuluh. Hanya tiga persen penyuluh yang sudah memiliki internet pribadi. Dalam pemanfaatannya, informasi yang diakses adalah bersifat hiburan, ekonomi dan bisnis, dan keperluan lainnya seperti e-mail. Begitupun rataan skor pemanfaatan media ini sangat rendah. Itulah sebabnya intensitas pemanfaatan media internet ini tidak berpengaruh nyata terhadap peningkatan kompetensinya.

Karakteristik penyuluh pertanian yang diteliti Anwas (2009) secara umum memiliki tingkat pendidikan tinggi (S1). Tingkat pendidikan memiliki keterkaitan dengan kepekaan dalam mendapat-kan informasi dari media massa. Menurut Tichenor
(Severin dan Tankard, 2001) tingkat pendidikan individu merupakan faktor penting dalam memperoleh informasi (pemanfaatan) dari media massa, karena pendidikan mempersiapkan orang untuk suatu tugas pemprosesan informasi dasar seperti membaca, memahami, dan mengingat. Begitupun menurut Straubhaar dan LaRose (2002), bahwa media massa dalam kaitanya dengan pembelajaran, setelah individu meng-konsumsi suatu media, individu tersebut akan berpikir, bersikap, dan melakukan suatu tindakan, yang diakibatkan oleh pengaruh media tersebut. Bila media itu memberikan pengaruh positif kepada dirinya, maka akan mengulang untuk mengkonsumsi media yang memiliki karakteristik yang sama. Demikian sebaliknya apabila mendapatkan hal yang negatif, maka ia akan menolak media yang memiliki karakteristik seperti itu.

Hasil penelitian Anwas (2009) tersebut dapat disimpulkan bahwa karakteristik media massa yang dimungkinkan dapat mempengaruhi perilaku masyarakat adalah media massa yang: 1) mudah diakses atau dijangkau oleh sasaran, 2) substansi atau konten dari media massa tersebut sesuai dengan kebutuhan sasaran, serta 3 ) dilakukan secara bertahap dan terus menerus (kontinyu). Selain itu seiring dengan tingkat persaingan media massa yang semakin ketat, maka kemasan media massa harus menarik dan menyenangkan. Konsep ini yang sering disebut dengan istilah edutainment.

\section{Media Massa dalam Keteladanan Sosial}

Teori belajar sosial (social learning theory) dengan tokohnya Albert Bandura seringkali disebut teori belajar observasional atau modeling. Menurut Bandura (1977), manusia dapat belajar dengan mengamati dan meniru perilaku orang lain. Peniruan model menjadi unsur penting dalam belajar. Hal ini terjadi dalam kehidupan keseharian masyarakat sehari-hari, bahwa belajar dapat dilakukan dengan mengamati dan meniru perilaku orang lain dalam mengubah atau untuk membentuk perilakunya.

Hasil penelitian Bandura menunjukkan bahwa anak-anak lebih agresif setelah menonton model agresif, film agresif atau kartun kekerasan dibandingkan dengan anak-anak yang melihat model yang tidak agresif atau tanpa model sekalipun (Woolfolk dan Nicolich, 1984). Teori belajar sosial ini merupakan 
kombinasi teori belajar behavioristik dan kognitif. Belajar atau pembentukan perilaku menurut teori belajar sosial adalah tidak harus dilakukan sendiri dalam diri pebelajar. Dalam realitasnya banyak orang melakukan proses belajar dengan mengamati dan meniru perilaku orang lain yang menjadi model atau idolanya.

Dalam teori pembelajaran sosial Bandura, ditegaskan bahwa dalam proses pembelajaran diperlukan adanya pigur atau contoh keteladanan. Keteladanan ini dari tokoh yang menjadi penutan dari peserta didik, misalnya orangtua, guru, tokoh masyarakat, tokoh agama, tokoh pemerintah dan termasuk tokoh politik. Ketokohan ini perlu dicerminkan dalam kehidupan nyata sehari-hari dalam berinteraksi dengan peserta didik. Artinya menanamkan pendidikan karakter terutama pada anak-anak dan remaja, tidak cukup keteladanan dalam berpikir, sikap, dan perilaku seorang guru atau orangtua saja. Keteladanan sangat diperlukan bagi semua orang mulai dari orangtua, guru, tetangga, yang tokoh masyarakat, tokoh politik, tokoh agama, dan siapapun yang dapat menjadi panutan bagi anak didiknya.

Dalam era informasi, media massa merupakan bagian dari kehirupan masyarakat yang tidak dapat dipisahkan. Masyarakat, khususnya anakanak dan remaja terutama setiap hari menghabiskan waktu untuk menonton televisi, mendengarkan radio, membaca koran, atau mengakses berbagai situs yang ada di internet. Exposure informasi atau sajian yang ada dalam media massa terhadap anak didik yang secara kontinyu tersebut akan memberikan kontribusi terhadap perubahan perilaku mereka. Manusia adalah mahluk peniru dan imitatif. Perilaku imitatif ini sangat menonjol pada anak-anak dan remaja. Saat ini seringkali yang menjadi idola anak dan remaja adalah para selebriti yang sering muncul di media massa. Oleh karena itu, untuk membentuk karakter pada anak diperlukan partisipasi media massa dalam mengemas substansi yang mendukung pembangunan karakter bangsa.

Dalam teori-teori belajar mazhab behaviorisik menekankan pentingnya faktor ekstrenal sebagai faktor penting keberhasilan dalam belajar atau mengubah perilaku sesuai yang diharapkan. Menurut mazhab behavioristik bahwa pola-pola perilaku itu dapat dibentuk melalui proses pembiasaan dan pengukuhan (reinforcement) dengan mengkondisi- kan stimulus (conditioning) dalam lingkungan (environmentalistik) individu yang bersangkutan (Makmun, 2005).

Untuk mengkondisikan agar lingkungan di sekitar anak dan remaja mendukung untuk mengubah perilaku dalam membangun karakter bangsa, maka aspek-aspek yang ada di sekitar lingkungan tersebut perlu mendukung pula. Salah satu aspek lingkungan di era informasi saat ini adalah media massa. Media massa sesuai dengan karakteristiknya dapat menyajikan pesan edukatif terutama pendidikan karakter bangsa.

Media massa dituntut untuk menyajikan perilaku keseharian yang menjadi contoh dalam mengkondisikan masyarakat untuk membangun pendidikan karakter. Dalam acara televisi misalnya, sinetron Si Doel Anak Sekolahan, Lorong Waktu, Bajaj Bajuri merupakan acara yang mengangkat realitas keseharian yang kaya dengan pesan moral. Disinilah media massa diuji untuk memiliki idealisme yang kuat dalam menyajikan pesan dan informasi kepada khalayak sebagai bentuk keteladanan sosial.

\section{Media Massa Publik}

Media massa memiliki fungsi sebagai media untuk informasi, hiburan, dan juga sebagai media pendidikan. Namun realitasnya media massa lebih banyak menonjol aspek hiburan dan informasi. Di sisi lain menurut Mulyana (2008) fungsi-fungsi pers saat ini telah bergeser (kini plus menyesat-kan, membodohi, meninabobokan, memanjakan, dan sebagainya), meskipun fungsi lama hingga derajat tertentu masih berlaku. Kondisi tersebut dapat dengan mudah ditemukan dalam tayangan media massa terutama dalam sajian di televisi dan internet.

Setiap media massa memiliki ideologi masingmasing. Namun, kepentingan dan sajian informasi yang berimbang harus menjadi acuan utama. Keberpihakan media massa seharusnya pada kepentingan masyarakat, namun praktenya lebih berat pada kepentingan pemilik (owner). Dalam sajian informasi misalnya, media massa bisa memilih topik informasi dan nara sumber tertentu, bahkan memberikan penekanan tertentu yang sejalan dengan ideologi dan kepentingan sang pemilik. Kondisi ini jelas membingungkan, membodohi, dan juga menyesatkan terhadap masyarakat. Oleh karena itu, untuk membangun media massa yang 
berpihak kepada masyarakat, kepemilikan (owner) media massa harus dimiliki oleh publik. Sulit rasanya memberikan keper-cayaan kepada media massa milik swasta agar konsisten pada kepentingan dan membangun masyarakat. Mereka memiliki ideologi, kepen-tingan, termasuk pertimbangan keuntungan finansial.

Membangun media massa yang bisa menanamkan pendidikan karakter sulit terwujud apabila apabila media tersebut dikuasai oleh swasta yang memiliki kepentingan dan hidden agenda. Oleh karena itu, untuk menciptakan media massa yang dapat membangun karakter bangsa perlu dibangun media yang benar-benar berpihak pada kepentingan masyarakat, yaitu dengan cara membangun media massa publik. Media massa publik tersebut bentuknya adalah koran publik, majalah publik, radio publik, televisi publik, dan situs-situs internet publik.

Media massa publik dimaksudkan sebagai media massa yang mengutamakan pada kepentingan masyarakat. Media ini harus memiliki idealisme yang kuat untuk menyuarakan dan membela kepentingan masyarakat, menghibur masyarakat, serta menjadi media yang bisa mencerdaskan serta meningkatkan ahklak dan karakter bangsa.

Anggaran operasional sepenuhnya disiapkan melalui APBN dan APBD. Dengan cara ini media massa ini diharapkan memiliki idealisme dalam menyajikan pesan dan informasi tanpa ketergantungan pada pengaruh sponsor.

Media massa publik kepemilikannya adalah pemerintah baik pemerintah pusat maupun daerah. Pengelolaan diserahkan pada lembaga indenpenden yang bertanggungjawab kepada publik. Direksi dan pimpinan media massa publik ini dipilih oleh Tim Indenpenden. Pemilihan oleh wakil rakyat yang berasal dari berbagai partai politik cenderung memiliki kepentingan dan keberpihakan pada kepentingan golongan dan partainya. Akibatnya orang yang dipilih cenderung kurang profesional, bisa berasal dari golongannya atau mau bekerjasama dengan kepentingan mereka.

Direksi atau pimpinan lembaga ini harus berasal dari orang-orang yang profesional dan ahli dalam bidangnya. Kemampuan ini sangat perlu karena media massa ini harus bersaing dengan media massa lainnya yang hanya menonjolkan aspek hiburan saja. Tantangan SDM media massa publik sangat berat. Merak dituntut mampu mendesain sajian acara yang tidak sekedar menarik tetapi juga bermanfaat dalam meningkatkan kualitas kecerdasan dan kehidupan masyarakat.

Televisi Republik Indonesia (TVRI) dan Radio Republik Indonesia (RRI) saat ini sudah menjadi Lembaga Penyiaran Publik atau menjadi televisi publik. Masalah TVRI dan RRI sebagai media massa publik saat ini terkait dengan citra atau image yang rendah. Akibatnya masyarakat kurang tertarik menonton TVRI atau mendengarkan RRI. Padahal mungkin saja ada acara TVRI dan RRI yang secara kualitasnya bagus. Namun image itulah yang menjadikan asumsi masyarakat bahwa semua acara TVRI/RRI di bawah televisi dan radio swasta.

Kendala lain adalah, TVRI/RRI belum mampu melayani kebutuhan masyarakat sesuai dengan fungsi media massa yang tidak hanya hiburan dan informasi tetapi juga aspek pendidikan termasuk pendidikan karakter. Oleh karena itu, TVRI/RRI idealnya memiliki minimal tujuh channal yang mengudara secara nasional selama 24 jam. Dengan menggunakan teknologi digital, penambahan channal TVRI/RRI sangat dimungkinkan, karena teknologi digital dapat menghemat penggunaan frekuensi yang ada. Setiap channal menyiarkan acara yang khusus yang terkait dengan kebutuhan dasar manusia, yaitu: informasi (news), budaya, pendidikan, pertanian, kesehatan, kewirausahaan, dan hiburan. Untuk mengisi substansi dalam setiap channal, TVRI/RRI bekerjasama dengan kementerian atau instansi terkait. Misalnya, substansi pendidikan bekerjasama dengan Televisi Edukasi dan radio Suara Edukasi di Kementerian Pendidikan dan Kebudayaan. Cara seperti ini sudah dilakukan TV pemerintah China yaitu Center of China Television yang memiliki 10 channal sehingga tiap channal menyiarkan subtansi dan sasaran yang lebih spesifik.

Aspek lainnya yang perlu dibenahi di TVRI/RRI adalah pemilihan direksi oleh anggota DPR. Dengan latar belakang anggota dewan dari multi partai, dimungkinkan adanya konflik antara kepentingan rakyat dan kepentingan partai/golongan. Idealnya direksi TVRI/RRI dipilih oleh lembaga indenpenden yang diawasi oleh masyarakat dan bertanggungjawab kepada publik. Dengan pemilihan seperti ini diharapkan dapat menjaring pimpinan TVRI/RRI yang lebih profesional sehingga bisa memecahkan berbagai masalah dan kendala dalam organisasinya, serta pada 
akhirnya bisa memenuhi harapan masya-rakat sebagai media massa publik.

Media massa cetak publik (koran publik dan majalah publik) perlu dibangun guna memberikan pencerahan dan pendidikan kepada masyarakat. Media cetak publik juga berfungsi mengimbangi gencarnya penerbitan media cetak swasta. Pengembangan media cetak publik ini bisa dilakukan melalui lembaga yang telah ada misalnya Kantor Berita Antara bekerjasama dengan kementerian dan instansi terkait. Begitu pula media internet, pemerintah perlu membangun infrastruktur yang mudah diakses dan dimanfaatkan, serta konten yang dapat memenuhi kebutuhan informasi masyarakat, khususnya substansi dalam mendidik karakter bangsa. Realitasnya hampir semua kementerian dan instansi pemerintah memiliki situs atau web tertentu. Di sisi lain, web atau portal pribadi semakin bermunculan. Dalam hal ini perlu adanya institusi yang bisa mengkoordinasikan dan melakukan standarisasi sehingga informasi yang ada dalam situs-situs tersebut dapat kredibel dan bermanfaat dalam meningkatkan kualitas kehidupan publik.

\section{Media Publik untuk Pendidikan Karakter}

Perbedaan media massa publik dengan media massa swasta adalah lebih menonjolkan kepentingan masyarakat terutama dalam aspek pendidikan dan pembelajaran yang mampu mencerdaskan, mendidik, dan meningkatkan kualitas kehidupan bangsa. Merujuk konsep media pembelajaran menurut Gagne dan Briggs (Sadiman dkk, 1986) bahwa media tersebut harus dapat merangsang sasaran untuk belajar. Artinya media massa publik dituntut dapat mendorong dan menciptakan lingkungan masyarakat untuk mau dan mampu belajar. Media ini harus menjadi inspirasi dan acuan masyarakat untuk kemajuan dan peningkatan kemampuan dan kualitas kehidupannya.

Secara lebih khusus dalam penanaman pendidikan karakter, media massa publik perlu memberikan sajian contoh keteladanan dalam membangun karakter bangsa. Untuk itu, media massa publik dapat mendesain substansi media dengan memperhatian hal-hal berikut ini.

Pertama, Keragaman budaya dan kearifan lokal merupakan bahan sajian media massa yang kaya dan menarik. Dalam budaya dan kearifan lokal terkandung nilai dan norma luhur sebagai jati diri karakter bangsa. Penyajian budaya dan kearifan lokal ini disajikan dalam penerapan kehidupan keseharian, serta menonjolkan aspek manfaat bagi masyarakat dan lingkungannya. Dengan demikian, sajian media massa dapat menjadi contoh khususnya bagi generasi muda. Sajian budaya dan kearifan lokal ini tidak terbatas pada budaya kaum mayoritas, akan tetapi kaum minoritas dan suku-suku terasing perlu mendapat tempat.

Kedua, Sajian tentang realitas kehidupan keseharian dalam mentaati hukum, aturan, sopan santun dalam kehidupan sehari-hari. Logikanya adalah orang yang mentaati aturan menjadikan kehidupannya selamat, senang, dan sukses, sebaliknya yang melanggar aturan berakhir dengan celaka atau masuk bui. Aspek ini dapat disajikan dalam berbagai format yang sesuai dengan karakteristik dari masing-masing media massa. Media televisi misalnya dapat menyajikan dalam format sinetron. Media radio disajikan dalam format sandiwara radio. Media koran atau majalah dapat menurunkan laporan kisah-kisah sukses orang yang patih dan taat kepada aturan atau hukum yang ada. Begitupun dalam internet dapat mengintegrasikan format televisi, radio, dan media cetak melalui konsep konvergensi media.

Ketiga, Realitas kehidupan masa anak-anak dan remaja merupakan topik penting dan menarik untuk mendapatkan prioritas dalam sajian media massa publik. Mengacu pada teori belajar sosial bandura, massa anak-anak dan remaja merupakan usia yang sering meniru terhadap perilaku sang tokoh. Tokoh anak dan remaja masa kini banyak yang muncul di media massa. Oleh karena itu, media massa publik perlu membangun atau menyajikan tokoh anak dan remaja yang memiliki karakter bangsa. Diharapkan ketokohan positif ini menjadi panutan bagi anak-anak dan remaja yang sedang mencari jati diri dalam membangun karakter dan kepribadiannya.

Keempat, Sajian informasi, hendaknya menyajikan berita tentang realitas sosial yang dapat membangun dan mensejahterakan masyarakat. Pemberitaan yang negatif hendaknya disertai dengan solusi atau pemecahannya. Misalnya ketika terjadi tawuran pelajar atau perselisihan antar suku, media tidak sekedar meliput apa adanya yang terjadi di 
lapangan. Dalam hal ini media memiliki kewajiban memberikan solusi atau pemecahan dalam mengatasi kasus tersebut.

Kelima, Dalam menyajikan wawancara atau talk show hendaknya dipilih tokoh atau masyarakat yang netral, seperti pakar, praktisi, atau para pelaku yang langsung terlibat di lapangan. Wawancara dengan tokoh politik atau organisasi tententu seringkali memiliki kepentingan golongan dan partai politiknya.

Keenam, Sajian hiburan yang mampu mendidik (edutainment). Sebagai media massa, acara hiburan menjadi aspek yang tidak dapat dipisahkan. Unsur hiburan dalam media massa publik dirancang tidak sekedar memberikan suasana santai tetapi hiburan yang dapat menjadi inspirasi dan bermanfaat. Misalnya, sinetron dokumentasi dramatisasi serial "Bukan Hanya Mimpi" yang disiarkan TPI bekerjasama dengan Yayasan Damandiri tahun 2002 s.d. 2005 mengangkat kisah nyata perjuangan pengusaha kecil (UKM) yang sukses dengan semangat keuletan dan kerja keras. Acara seperti ini tidak hanya menghibur dalam format dokudrama tetapi dapat menjadi inspirasi untuk berwirausaha.

Untuk dapat membangun karakter bangsa khususnya terhadap anak-anak dan remaja, sesuai kajian Anwas (2009), bahwa exposure media massa publik tersebut perlu dilakukan secara kontinyu, yang ditunjang oleh kemudahan akses untuk dimanfaatkan, serta subtansi yang sesuai dengan kebutuhan dan permasalahan yang dihadapi masyarakat khususnya anak-anak dan remaja. Di sisi lain pengemasan substansi media yang menarik sangat penting sehingga media massa publik memiliki daya saing dengan media massa milik swasta.

Kesadaran dan pemahaman orangtua dan masyarakat perlu ditumbuhkan terhadap media massa publik. Media massa tidak hanya sebagai media hiburan, tetapi sebagai media informasi dan juga pendidikan. Para orangtua dan masyarakat perlu dibiasakan memilih media massa yang bisa menanamkan nilai-nilai dan meningkatkan kualitas kehidupannya. Teori-teori efek komunikasi massa terutama Teori uses and gratifications menegaskan bahwa publik tidak tinggal diam dan menerima pesan-pesan media massa begitu saja. Oleh karena itu, masyarakat harus mendukung dengan cara memilih media massa publik sebagai media utama dalam memenuhi kebutuhan informasi dan pendidikan mereka. Mereka perlu dibiasakan dan dibudayakan untuk mengkritisi terhadap media massa yang dapat merusak tatanan nilai dan norma yang ada. Para orangtua dan masyarakat juga perlu mendukung, mengawasi, memberikan saran, dan mengontrol terhadap subtnasi dalam media massa publik.

Dukungan sekolah terhadap media massa publik adalah menyiapkan kondisi lingkungan yang kondusif, diantaranya melalui penyedian infrastruktur agar peserta didik dapat mudah mengaksesnya. Sekolah juga dapat mengintegrasikan proses pembelajaran dengan materi sajian yang ada di media massa publik. Pengintegrasian ini bisa dilakukan langsung dalam proses pembelajaran di kelas, kegiatan ekstra kurikuler, atau penugasan di luar jam sekolah.

Akhirnya pembangunan media massa publik sangat bergantung pada kebijakan pemerintah. Kebijakan ini diwujudkan dalam bentuk upaya merealisasikan media massa publik, baik melalui perangkat peraturan, pembentukan organisasi, penyediaan konten, serta membangun kesadaran dan kemampuan SDM masyarakat untuk memanfaatkan media massa publik sebagai media pendidikan dalam membentuk karakter bangsa.

\section{Simpulan dan Saran Simpulan}

Dalam era informasi, penanaman pendidikan karakter khususnya terhadap anak-anak dan remaja perlu dilakukan melalui media massa. Media massa dituntut memiliki idealisme yang kuat dalam menyajikan pesan karakter bangsa secara kontinyu. Kepemilikan media yang dikuasai swasta sulit untuk bisa mewujudkan idealisme tersebut. Media massa swasta disamping memiliki ideologi tertentu seringkali ditunggangi oleh kepentingan pemilik (owner), serta kepentingan untuk mendapatkan untung. Oleh karena itu, penanaman pendidikan karakter dalam media massa diperlukan pembangunan media massa publik.

Media massa publik dimaksudkan sebagai media massa yang mengutamakan pada kepentingan masyarakat. Media ini harus memiliki idealisme yang kuat untuk menyuarakan dan membela kepentingan masyarakat, menghibur masyarakat, serta menjadi media yang bisa mencerdaskan serta meningkatkan ahklak dan karakter bangsa. 
Bentuk media massa publik adalah media cetak yaitu Koran Publik atau Majalah Publik dan media elektronik yaitu Radio Publik, Televisi Publik, dan Web/ Portal Publik. Media ini dikelola oleh orang-orang profesional yang dipilih oleh tim indenpenden melalui seleksi yang ketat. Pertanggungjawaban dilakukan kepada publik. Masyarakat dapat aktif mengisi substansi, menga-wasi, mengkritisi, dan mengontrol penyelenggara-an layanan media massa publik. Anggaran operasional media ini sepenuhnya dibiayai oleh APBN dan APBD.

Untuk dapat menanamkan pendidikan karakter, substansi media massa publik perlu dirancang sesuai dengan kebutuhan dan karakter sasaran, distribusinya dilakukan secara kontinyu, mudah diakses atau dimanfaatkan oleh sasaran, serta dikemas dalam format yang menarik dan mampu bersaing dengan media massa swasta.

Secara substansi, media massa publik berbeda dengan media massa swasta. Substansi media ini dituntut dapat mendorong dan menciptakan lingkungan masyarakat untuk mau dan mampu belajar, menjadi inspirasi dan acuan masyarakat untuk kemajuan, serta memberikan contoh keteladanan dalam membangun karakter bangsa.

\section{Saran}

Untuk merealisasikan media massa publik kunci utamanya ada pada kebijakan pemerintah baik melalui perangkat peraturan, pembentukan organisasi, penyediaan, penyedian konten, serta membangun kesadaran dan kemampuan SDM masyarakat untuk memanfaatkan media massa publik sebagai media pendidikan dalam membentuk karakter bangsa.

Substansi media massa publik hendaknya didesain dengan bersumber pada keragaman budaya dan kearifan lokal masyarakat, sajian realitas kehidupan keseharian dalam mentaati hukum, aturan, sopan santun dalam kehidupan sehari-hari, sajian informasi yang dapat mencerdaskan, serta disajikan dalam format yang menghibur dan mendidik (edutainment).

Pembentukan media massa publik dapat dikembangkan dari lembaga penyiaran publik yang telah ada misalnya RRI, TVRI, atau Kantor Berita Antara serta mensinergikan dengan potensi yang dimiliki kementerian atau lembaga baik dalam aspek: substansi, infrastruktur, SDM, dan aspek lainnya. Misalnya, pengembangan TV Publik, Radio Publik, dan Portal Publik dapat mensinergikan dengan Televisi Edukasi, Radio Suara Edukasi, dan Portal Rumah Belajar yang dimiliki Kementerian Pendidikan dan Kebudayaan. Perlu dilakukan penelitian dan kajian lebih mendalam dalam merencanakan pembentukan dan penyeleng-garaan media massa publik, baik Koran Publik, Majalah Publik, Radio Publik, Televisi Publik, maupun Web/Portal Publik.

\section{Pustaka Acuan}

Anwas, 2009. Pemanfaatan Media dalam Pengembangan Kompetensi Penyuluh Pertanian. Disertasi: Program Studi Ilmu Penyuluhan Pembangunan Departemen Sains Komunikasi dan Pengembangan Masyarakat IPB Bogor.

Anwas, 2010. Televisi Mendidik Karakter Bangsa: Harapan dan Tantangan. Jakarta: Artikel Jurnal Pendidikan dan Kebudayaan. Vol. 16 Edisi Khusus III. Balitbang Kemdiknas.

Bandura, Albert. 1977. Social Learning Theory. New Jersey: Prentice-Hall Inc, Englewood Cliffs.

Elkind, David H dan Freddy Sweet. 2004. How to Do Character Education. http://www.goodcharacter.com/ Article_4.html (25 Mei 2011).

Kementerian Pendidikan Nasional. 2010. Pembangunan Pendidikan Nasional 2010-2014; Paparan Mendiknas Mohammad Nuh dalam Rembug Nasional Pendidikan 2010. Depok: 2-4 Maret 2010 www.dikti.go.id/.../Rembuknas2010/REMBUK-MENDIKNAS-2010-V-2.pdf (15 Agustus 2011. Makmun, Abin Syamsudin, 2005. Psikologi Kependidikan; Perangkat Sistem Pengajaran Modul. Bandung: Remaja Rosda Karya.

Mulyana, Deddy. 2008. Komunikasi Massa: Kontroversi, Teori, dan Aplikasi. Bandung: Widya Padjadjaran. McQuail, Denis. 1987. Teori Komunikasi Massa; Suatu Pengantar. Edisi Indonesia. Jakarta: Erlangga McQuail, Denis dan Sven Windahl. 1996. Communication models; for the study of mass communication. London \& New York:Longman.

Undang-Undang Nomor 20 Tahun 2003 tentang Sistem Pendidikan Nasional. 
Undang-Undang Dasar Negara Republik Indonesia Tahun 1945

Woolfolk, Anita E dan Nicolich, Lorraine McCune. 1984. Educational psychology for teachers. Second edition. Englewood Cliffs, New Jersey: Prentice Hall, In.

Sadiman, Arief S, R. Rahardjo, Anung Haryono, dan Rahardjito. 1986. Media Pendidikan: Pengertian, Pengembangan, dan Pemanfaatanya. Jakarta: Rajawali.

Sendjaja, Sasa Djuarsa, dan Ilya Sumawinardi. 1994. Teori Komunikasi; Materi Pokok Modul Universitas Terbuka, Jakarta: UT.

Severin, J Werner dan James W. Tankard. 2001. Communication Theory: Origin, Methods, and Uses in The Mass Media. Eddison Wesley Lngman, Inc.

Straubhaar, Joseph dan Rober LaRose. 2002. Media Now: Communications Media in the Information Age. Third Edition. Belmon. CA: Wadsworth.

Suresh, Kalyani. 2003. Journalism and Mass Communication; Theories of Communication.http:// www.peoi.org/Courses/Coursesen/mass/mass2.html (17 Oktober 2011) 